\title{
CHARACTERISTICS OF PETROLEUM FUELS AND DETERMINATION OF (POSSIBLE) ADULTERANTS IN PETROL/GASOLINE BY USING GAS CHROMATOGRAPHY ${ }^{1} 2$ (PETROCOL COLUMN ${ }^{3}$ )
}

B. Edison*

\begin{abstract}
This study explains a few aspects about the characteristics of the fuels like Motor gasoline, diesel and kerosene. Adulteration in the motor gasoline has been analyzed and methods to find the adulterants is explained here. Adulteration in the motor gasoline can be find out using "Gas Chromatography". This study also explains the role of the solvents as the adulterants.
\end{abstract}

Key words: Motor Gasoline, Gas Chromatography, Solvents, adulteration, Flame ionization detector, Suitable boiling point solvents, Retention time, Area \%.

* Research Chemist, CFTL, Chennai 


\section{Introduction}

Petroleum is one of the most important liquid fuels in the world. Present say material civilization would have been impossible without it. Gasoline, Petrol and Diesel, the main product obtained from a naturally occurring crude oil, called petroleum, supply power to automobiles. The crude is otherwise called rock oil or mineral oil. It is highly colored viscous liquid and occurs below the surface of the earth below strata of shale, limestone and clay at a depth of 500-1500 ft at various places. It is generally present with water and the natural gas forms a middle layer. The biggest oil producing country of the world is U.S.A., which produces more than $60 \%$ of the total world output.

\section{Origin}

Opinions are divided regarding the formation of petroleum. Any theory put forward to explain the origin of petroleum must explain the following important properties associated with the petroleum.

i) The presence of chlorophyll, haemin and resins.

ii) The presence of nitrogen and sulphur compounds.

iii) The optical activity.

iv) Its association with sodium chloride (brine)

A theory called inorganic origin put forward by Mendeleeff (1876) had failed due to the insufficient explanations about the optically active compounds. Engler's Organic origin was unable to explain the presence of the chlorophyll.

According to the modern views, natural petroleum is formed due to the decomposition of animal as well as vegetable matter. At some places, the petroleum is of animal origin and other places, it is of vegetable origin. This theory readily accounts for the presence of chlorophyll and occurrence of coal deposits in the neighborhood of oil deposits. It also accounts for the presence of high percentage of resins in oils. 


\section{Composition of Petroleum}

The composition of petroleum varies from place to place and crude petroleum is made up of hundreds of different individual chemicals, from methane to asphalt.

In general, most of the constituents are straight chain paraffins and aromatic hydrocarbons e.g. benzene, tolvene etc. The ultimate analysis of petroleum indicates that in addition to hydrocarbons (83-87\% of carbon and $11-15 \%$ of hydrogen) small quantities of nitrogen, sulphur, and oxygen are also present in it. Sulphur is present generally as alkylsulphides, hydrosulphides, hydrogen sulphide and thiophine and less frequently, combined oxygen is present as carboxylic acids (naphthalenic acids), ketones and phenols. The disagreeable odour of petroleum is due to the sulphur compounds present in it. The hydrocarbon present in the crude petroleum may be divided into two main classes.

Open chain or aliphatic compounds: $n$-paraffins series $\left(\mathrm{C}_{n} \mathrm{H}_{2 n-2}\right)$, isoparaffin series $\left(\mathrm{C}_{n} \mathrm{H}_{2 n+2}\right)$ and olefin series $\left(\mathrm{C}_{n} \mathrm{H}_{2 n}\right)$.

Ring Compounds: Naphthalene series $\left(\mathrm{C}_{n} \mathrm{H}_{2 n}\right)$ and aromatic series or benzene series.

In petroleum gaseous paraffins (hydrocarbons) from $\mathrm{CH}_{4}$ to $\mathrm{C}_{4} \mathrm{H}_{10}$ are present in dissolved state. The naphthenic hydrocarbons present in petroleum are mainly the derivatives of cyclopentane and cyclohexane.

\section{Petroleum Fractions}

\begin{tabular}{|c|l|c|c|}
\hline S.No. & \multicolumn{1}{|c|}{$\begin{array}{c}\text { Petroleum } \\
\text { Fraction }\end{array}$} & $\begin{array}{c}\text { Boiling } \\
\text { Range }{ }^{\circ} \mathrm{C}\end{array}$ & $\begin{array}{c}\text { Approximate no. of } \\
\text { Carbon atoms }\end{array}$ \\
\hline 1 & Petroleum Ether & $30-70$ & $\mathrm{C}_{5}-\mathrm{C}_{7}$ \\
\hline 2 & Gasoline & $40-140$ & $\mathrm{C}_{5}-\mathrm{C}_{9}$ \\
\hline 3 & Naphtha & $140-180$ & $\mathrm{C}_{9}-\mathrm{C}_{10}$ \\
\hline 4 & Kerosene & $180-250$ & $\mathrm{C}_{10}-\mathrm{C}_{16}$ \\
\hline 5 & Diesel & $250-320$ & $\mathrm{C}_{10}-\mathrm{C}_{18}$ \\
\hline
\end{tabular}




\section{Characteristics of Fuels}

\section{Petrol}

The petrol/gasoline has the boiling point range between 40 and $1400 \mathrm{C}$. The density of the petrol may lie between $710-770 \mathrm{~kg} / \mathrm{m}^{3}$. The distillation ${ }^{5 *}$ range starts and ends within this range, but sometimes the final boiling point may rise due to the presence of the (light) naphtha. The octane number is 88 for ordinary petrol and 93 for the premium petrol. The sulphur, benzene, gum content, antiknocking ${ }^{8}$ property and all the requirements are given below.

\begin{tabular}{|c|c|c|c|}
\hline S.No. & Tests & Method No. & Requirement \\
\hline 1 & Colour visual & IS 1448 (P: 16) & Orange \\
\hline 2 & Density at $15^{\circ} \mathrm{ckg} / \mathrm{m}^{3}$ & & $710-770$ \\
\hline 3 & $\begin{array}{l}\text { Distillation: } \\
\text { a) Recovery up to } 70^{\circ} \mathrm{C} \\
\text { (E70), \% by Vol. }\end{array}$ & IS 1448 (P: 18) & $10-45$ \\
\hline & $\begin{array}{l}\text { b) Recovery up to } 100^{\circ} \mathrm{c} \\
\text { (E100), \% by Vol. }\end{array}$ & & $40-70$ \\
\hline & $\begin{array}{l}\text { c) Recovery up to } 180^{\circ} \mathrm{C} \\
\text { (E180), \% by Vol. }\end{array}$ & & $90 \mathrm{Min}$ \\
\hline & $\begin{array}{l}\text { d) Final Boiling Point } \\
\text { (FBP) }{ }^{\circ} \mathrm{C}\end{array}$ & & $215 \mathrm{Max}$ \\
\hline & e) Residue, \% by Vol. & & $2 \operatorname{Max}$ \\
\hline 4 & $\begin{array}{l}\text { Research Octane Number } \\
\text { (RON) }\end{array}$ & IS 1448 (P: 26) & $88 \mathrm{Min}$ \\
\hline 5 . & Anti-Knock Index (AKI) & $\begin{array}{r}1 S 1448 \text { (P: 26) } \\
\& 1 S 1448 \text { (P: 27) } \\
\end{array}$ & $84 \mathrm{Min}$ \\
\hline 6 & Existent gum, $\mathrm{g} / \mathrm{m}^{3}$ & $\begin{array}{l}\text { IS } 1448 \text { (P: 29) } \\
\text { Air jet solvent } \\
\text { washed }\end{array}$ & 40 Max \\
\hline 7 & Potential gum, $\mathrm{g} / \mathrm{m}^{3}$ & IS 1448 (P: 147) & 50 Max \\
\hline 8 & Sulphur, total, $\%$ by mass & IS 1448 (P: 34) & $0.10 \mathrm{Max}$ \\
\hline 9 & Lead content (as Pb), g/l & $\begin{array}{l}\text { ASTM D5059 or } \\
\text { IP } 352\end{array}$ & $0.013 \mathrm{Max}$ \\
\hline
\end{tabular}




\begin{tabular}{|l|l|l|l|}
\hline 10 & Reid Vapour Pressure (RVP), Kpa & IS 1448 (P: 39) & $35-60$ \\
\hline 11 & $\begin{array}{l}\text { Vapour Lock Index, } \\
\text { (VLI=10RVP+7E70) }\end{array}$ & 950 Max \\
\hline 12 & Benzene content, \% by volume & ASTM D3606 & 3.0 Max \\
\hline 13 & $\begin{array}{l}\text { Copper strip corrosion for } \\
3 \text { hr at 50 } \mathrm{C}\end{array}$ & IS 1448 (P: 15) & $\begin{array}{l}\text { Not worse } \\
\text { than number 1 }\end{array}$ \\
\hline
\end{tabular}

\section{Diesel}

The Diesel is an important fuel for our day-to-day life. Its density is 810 to $870 \mathrm{~kg} /$ $\mathrm{m}^{3}$. The distillation range starts from $150^{\circ} \mathrm{C}$ and ends around $380^{\circ} \mathrm{C}$. This may be due to the presence of some amount of kerosene and some heavy oils. The flashpoint' is an important property to the diesel for the storage purpose; it should be greater than $35^{\circ} \mathrm{C}$. It is found out by using Abel flashpoint apparatus. Flash point ${ }^{\circ} 66^{\circ} \mathrm{C}$ is applicable for Naval applications only for high flash HSD including Merchant Navy and fishing vessels of $12 \mathrm{~m}$ in length. Pensky Marten's apparatus can determine it. The pour point ${ }^{11}$ is a vital experiment to find the cease point of the fuel especially in the hilly places. The kinematic viscosity ${ }^{12}$ is also a significant test for this fuel to test the quality of the diesel. It should be 2.0-5.0 CST. The cetane index is also important factor in the diesel. The percentage of carbon can be found out by the Rams bottom method, the carbon residue should be $0.30 \%$ by mass, and the acidity, ash limitations are given below.

\begin{tabular}{|l|l|l|l|}
\hline S.No. & \multicolumn{1}{|c|}{ Tests } & \multicolumn{1}{|c|}{ Method No. } & Requirement \\
\hline 1 & Acidity, inorganic & IS $1448(\mathrm{P}: 2)$ & Nil \\
\hline 2 & Acidity, Total, $\mathrm{mg}$ of $\mathrm{KOH} / \mathrm{g}$ & IS $1448(\mathrm{P}: 2)$ & $0.20 \mathrm{Max}$ \\
\hline 3 & Ash, \% by mass & IS 1448 (P: 4$)$ & $0.01 \mathrm{Max}$ \\
\hline 4 & $\begin{array}{l}\text { Carbon residue (Rams bottom) } \\
\text { on 10\% Residue \% by mass }\end{array}$ & IS $1448(\mathrm{P}: 8)$ & $0.30 \mathrm{Max}$ \\
\hline 5 & Cetane Index & ASTMD 4737 & $46 \mathrm{Min}$ \\
\hline 6 & Pour Point, ${ }^{\circ} \mathrm{C}$ & IS $1448(\mathrm{P}: 10)$ & $15 \mathrm{Max}$ \\
\hline 7 & $\begin{array}{l}\text { Copper strip corrosion for 3 h } \\
\text { at 100 deg. c }\end{array}$ & IS $1448(\mathrm{P}: 15)$ & $\begin{array}{l}\text { Not worse } \\
\text { than No.1 }\end{array}$ \\
\hline
\end{tabular}




\begin{tabular}{|c|c|c|c|}
\hline 8 & Distillation, $\% v / v$, recovered & IS 1448 (P: 18) & \\
\hline & $\begin{array}{l}\text { a) At } 350^{\circ} \mathrm{C} \\
\text { b) At } 370^{\circ} \mathrm{C}\end{array}$ & & $\begin{array}{l}85 \mathrm{Min} \\
95 \mathrm{Min}\end{array}$ \\
\hline 9 & Flash Point, Abel, ${ }^{\circ} \mathrm{C}$ & IS 1448 (P: 20) & $35 \mathrm{Min}$ \\
\hline 10 & $\begin{array}{l}\text { Kinematic viscosity at } \\
40^{\circ} \mathrm{C}, \mathrm{CSt}\end{array}$ & IS 1448 (P: 25) & $2.0-5.0$ \\
\hline 11 & Sediment, $\%$ by mass & IS 1448 (P: 30) & $0.05 \mathrm{Max}$ \\
\hline 12 & Density at $15^{\circ} \mathrm{c}, \mathrm{kg} / \mathrm{m}^{3}$ & $\begin{array}{l}\text { IS } 1448(\mathrm{P}: 16) \\
\text { or (P: 32) }\end{array}$ & $820-860$ \\
\hline 13 & $\begin{array}{l}\text { Total sulphur, percentage by } \\
\text { mass }\end{array}$ & $\begin{array}{l}\text { IP } 336 \text { or } \\
\text { IS } 1448 \text { (P: 33) }\end{array}$ & $0.25 \mathrm{Max}$ \\
\hline 14 & Water content, $\%$ by volume & IS I 448 (P: 40) & $0.05 \mathrm{Max}$ \\
\hline 15 & $\begin{array}{l}\text { Cold filter plugging point } \\
\text { (CFPP), }{ }^{\circ} \mathrm{C}\end{array}$ & IS 1448 (P: 110$)$ & 18 Max \\
\hline 16 & Total sediments, $\mathrm{mg} / 100 \mathrm{ml}$ & ASTM D2274 & 1.5 Max \\
\hline
\end{tabular}

\section{Kerosene}

The kerosene's distillation range starts from the $150^{\circ} \mathrm{C}$ to $250^{\circ} \mathrm{C}$. To avoid the adulteration of diesel using kerosene the dye is added with the colorless kerosene. The flash point of the kerosene may be greater than $35^{\circ} \mathrm{C}$.

\begin{tabular}{|l|l|l|l|}
\hline S.No. & \multicolumn{1}{|c|}{ Tests } & Method No. & Requirement \\
\hline 1 & Colour Say bolt & IS 1448 (P: 14) & Plus 10, Min \\
\hline 2 & $\begin{array}{l}\text { Distillation } \\
\text { a) Percent recovered below } \\
200^{\circ} \mathrm{C}\end{array}$ & IS 1448 (P: 18) & 20 Min300 \\
b) Final boiling point ${ }^{\circ} \mathrm{C}$ & & \\
\hline 3 & Flash point, Abel, ${ }^{\circ} \mathrm{C}$ & IS 1448 (P: 20) & 35 Min \\
\hline 4 & Smoke point, $\mathrm{mm}$ & IS 1448 (P: 31) & 18 Min \\
\hline
\end{tabular}




\begin{tabular}{|l|l|l|l|}
\hline 5 & $\begin{array}{l}\text { Burning Quality } \\
\text { a) Char value, mg/kg of oil } \\
\text { consumed } \\
\text { b) Bloom on chimney, } \\
\text { predominating colour } \\
\text { c) Bloom on chimney, general } \\
\text { appearance }\end{array}$ & IS 1448 (P: 5) & 20 Max \\
\hline 6 & Acidity, inorganic, $\mathrm{KOH} / \mathrm{gm}$ & IS $1448(\mathrm{P}: 2)$ & $\begin{array}{l}\text { Not darker } \\
\text { than gray }\end{array}$ \\
\hline 7 & Sulphur, fotal, \% by mass & IS $1448(\mathrm{P}: 34)$ & $0.25 \mathrm{Max}$ \\
\hline 8 & $\begin{array}{l}\text { Copper strip corrosion for } \\
3 \text { hrs at } 100^{\circ} \mathrm{C}\end{array}$ & IS $1448(\mathrm{P}: 15)$ & $\begin{array}{l}\text { Not worse } \\
\text { than No.1 }\end{array}$ \\
\hline 9 & Density at $15^{\circ} \mathrm{C}, \mathrm{g} / \mathrm{ml}$ & IS $1448(\mathrm{P}: 16)$ & Report \\
\hline
\end{tabular}

The distillation procedure for petrol, diesel and kerosene, and the testing condition is different in each case. For petrol the distillation flask is cooled, the bath temperature is maintained at 0 to $4^{\circ} \mathrm{C}$ and the collecting jar temperature is maintained at 10 . $15^{\circ} \mathrm{C}$. The tiles, which is used to fix the distillation flask, has $38 \mathrm{~mm}$ diameter hole. In the case of kerosene the bath temperature is kept as ambient and the collecting jar is also maintained at ambient temperature. For diesel the bath temperature is increased and maintained at about $40-60^{\circ} \mathrm{C}$ and the collecting jar is at room/ ambient temperature.

\section{Important Criteria of Fuel}

Knocking is a "sharp metallic sound similar to ratting of hammer, which is produced in the internal combustion engine owing to immature ignition of the air gasoline mixture". Knocking tendency of paraffins increases with the increase in the length of the carbon chain. Branched chain paraffins have lower tendency to knock and so have higher octane numbers. The aromatic hydrocarbons have less knocking tendency than Naphthenes. Straight run gasoline has higher knocking properties. Knocking property is expressed as octane number or octane rating. Normally to increase the antiknocking property the oil companies add some compounds called antiknock compounds like Tetra Ethyl Lead (TEL). Usually a mixture called ethyl fluid (tetra ethyl lead $63 \%$, ethylene bromide $26 \%$, ethylene dichloride $9 \%$, and a dye called methylene blue $2 \%) 1-3 \mathrm{cc}$. of this mixture is added to one gallon of gasoline. Now Tetra Methyl Lead (TML) has been found better than TEL, new compound cyclopentadienyl manganese carbonyl is used, to avoid lead pollution. 
Octane Number: "The percentage of iso-octane in a mixture of iso-octane and $\mathrm{n}$-heptane that has the same knocking characteristics of the fuel under examination in a standard one cylinder engine operated under conditions. The higher the octane number of the fuel, the highest is its antiknocking property." For example, the fuel with octane number 60 would give the same knocking as a mixture by volume of $60 \%$, iso-octane and $40 \% n$-heptane. In other words, the gasoline having an octane number of 60 , behaves like a mixture of $60 \%$ iso-octane and $40 \% n$ heptane. Octane number decreases with increase in chain length. The hydrocarbon tripentane (2,2,3-trimethyl butane) is superior to iso-octane, because its octane number 124. Therefore, gasoline obtained by cracking has higher octane number because it contains higher percentage of alkenes. Thus octane number is related to molecular mass and structure. For example, octane numbers of propane, $n$-butane, $\mathrm{n}$-pentane, $\mathrm{n}$-hexane, $\mathrm{n}$-heptane, $\mathrm{n}$-octane and $\mathrm{n}$-nonane are $100,92,61,25,0$, -27 and -45 respectively. Similarly octane numbers of $n$-heptane, 2 -methyl hexane, 2,3-dimethyl pentane and 2,2,3-trimethyl butane are $0,45,93$ and 116 respectively.

\section{Adulteration Possibilities}

The government of India gives some specifications for the fuels like gasoline, diesel and kerosene etc. through the Bureau of Indian Standards. (BIS). The adulteration in petrol due to the mixing of kerosene was found out by the Furfural test (using furfuraldehyde). Normally oil companies add furan-2-aldehyde in kerosene to avoid the adulteration of petrol. When petrol samples are tested with Furfural test (i.e., aniline acetate is added to petrol the presence of the red color shows the adulteration of kerosene in petrol). But sometimes the oil companies don't add furfural in kerosene and the adulteration of petrol by kerosene is also reduced. The crucial factor is the price of kerosene. Due to hike in the price, the utility of kerosene is highly reduced. Instead of kerosene they use the solvents as the adulterants. The physical tests like distillation and density show the kerosene adulteration. Though the gasoline is an adulterated one it also meets the specification given by the BIS. This is due to the adulteration of petrol by different solvents. The adulteration using kerosene is an old method. Now the adulteration done by proper technique, it is nothing but adulteration using solvents especially using Suitable Boiling Point (SBP) solvents.

There are so many SBP solvents which are readily available in the market. The SBP solvents are being used as the adulterants since the price is lower than kerosene.

Another important concept is the boiling point of the solvents; they have the similar boiling points as the petrol and its components, the price is also less than kerosene. The quantity of solvents especially paraffins reduce the octane number so they add 
the octane boosters i.e., the least carbon paraffins and olefins have the higher octane number, so when it is mixed with petrol as the adulterants it boost the octane number. Usually olefin forms gum frequently so to avoid the gum formation refineries add antioxidants like $\mathrm{N}, \mathrm{N}^{\prime}$-disecondary-butyl-paraphenylene diamine; 2,4-dimethyl-6-tertiary butyl phenol; 4-methyl-2, 6-ditertiary-butyl phenol; $N, N^{\prime}$ isopropyl-paraphenylene diamine; $N$, normal butyl-p-aminophenol. Generally oxygenates like methanol, ethanol, isopropanol, 2-butanol, tert-butanol, methyl tertiary butyl ether (MTBE), ethyl tertiary butyl ether (ETBE), tertiary amyl methyl ether (TAME), diisopropyl ether (DIPE) are added .

The excess of oxygenates, aromatics may create knocking in the engines but not good for engines and harmful for our health since it gives sooty smoke, (which cause breathing troubles and cancer). The oxygenates like 1,2-dichloro propane, isomers of hexane, heptane and pentane are in petrol.

The presence of the olefins form gum, which spoil the engines. We can find out the amount of the gum content by the BIS methods existent gum, $\mathrm{g} / \mathrm{m}^{3}$ - IS 1448 Air jet solvent washed and Potential gum, $\mathrm{g} / \mathrm{m}^{3} \mathrm{IS} 1448$. But the excess amount of the aromatics in petrol can only be find out by the Gas Chromatography method. By using proper column we can find out the percentage of the oxygenates, paraffins and aromatics like benzene, toluene, $o-x y l e n e, p-x y l e n e, m-x y l e n e$, ethyl benzene, propyl benzene, 2-ethyl toluene.

\section{Gas Chromatography Method}

Gas Chromatography is a separation technique, using gas as a mobile phase, in a column with stationary phase being a solid support or inert solid support coated with liquid phase. Separation is due to the Differential Distribution Coefficients.

This method determines the majority of individual hydrocarbon components of gasoline with boiling ranges up to $250^{\circ} \mathrm{C}$. Individual components or groups of coeluting components are determined from 0.001-100 mass percent. Mixtures with $\mathrm{C}_{4}-\mathrm{C}_{8}$ olefins at concentrations up to thirty percent mass can be analyzed. This method is also applicable to mixtures containing alcohols or ethers.

\section{Instrumentation}

Gas chromatograph (GC) Chemito GC1000 equipped with a Flame Ionization Detector (FID), a split/splitless capillary injector, a 100 meter long and $0.25 \mathrm{mmlD}$ Pefrocol DH-100 (supelco) and a precolumn of 2-3 meters long analytical column 
used. Micro syringe 2.0 micro liter for injection, only $0.2 \mu \mathrm{L}$ is injected into the GC. From the injected sample, only a small amount gets into the column, to regulate this amount of sample use split ratio ${ }^{13}$ normally we use 1:80 split ratio for this purpose. Chemitochrom 2000 software used for the detection of the components. DHA is an advanced software to find out the exact contents of the hydrocarbon mixture /MS.

But this study is based on the usage of the GC-FID ${ }^{14-24}$ without the Detailed Hydrocarbon Analysis (DHA) software.

\section{Principle and Application}

The function is based on the principle that different components in a mixture are attracted differently and absorbed on solid absorbents.

There is a carrier gas $(\mathrm{He})$ flowing at a particular speed through a column that is kept in oven.

The conditions for the $G C$ is given as below

Column: 100 meter Petrocol DH

Injection Temperature: $250^{\circ} \mathrm{C}$

Detection Temperature: $265^{\circ} \mathrm{C}$

Oven Temperature: $40^{\circ} \mathrm{C}-200^{\circ} \mathrm{C}$

Rate of heating: $3^{\circ} \mathrm{C} / \mathrm{min}$.

Ramping: 40-1.00min. $-3^{\circ} \mathrm{C} / \mathrm{min}$.; $200-1.00 \mathrm{~min}$.

Oxidant: Zero air (99.999\%)

Make up gas and Carrier gas: Helium (99.999\%)

Fuel gas: Hydrogen (99.999\%)

- The components of the sample are carried away by the carrier gas through the column.

- The adsorbent differently attracts and hence controls the speed of the components of the mixture.

- The components which is least attracted is to leave the column first and the most attracted component leaves the column last. 
- The sample that enters the detector, Flame lonization Detector (FID) where it is entirely vaporized. During combustion positive and negative ions are produced which are controlled over the respective electrodes and the current produced proportional to the ions collected in the form of analog signals, then converted into the digital signals and is monitored, detected in the form of chromatogram.

- The recorder plots the current produced for the combustion of each component possess its characteristic Retention Time (RT). The Chromatograms obtained by plotting retention time against area percent (in terms of $\mathrm{mV}$ ). Retention Time is the time taken by the component to leave the column. The area percent is the amount of organic components present in the total mixture.

\section{Interpretation and Conclusion}

When inject some individual solvents we can get the chromatogram like Chromatogram 1. According to the Retention index, the components elute at different Retention Times. The given below is a mixture of solvents. Here the solvent mixture is injected that mixture contains acetone, pentane, hexane, benzene, cyclohexane, isooctane, heptane, tolvene, p-xylene, o-xylene.

From this Chromatogram 1 we clearly identify the above-mentioned solvents, with their Retention time.

\section{Chromatogram 1: The mixture of Solvents}

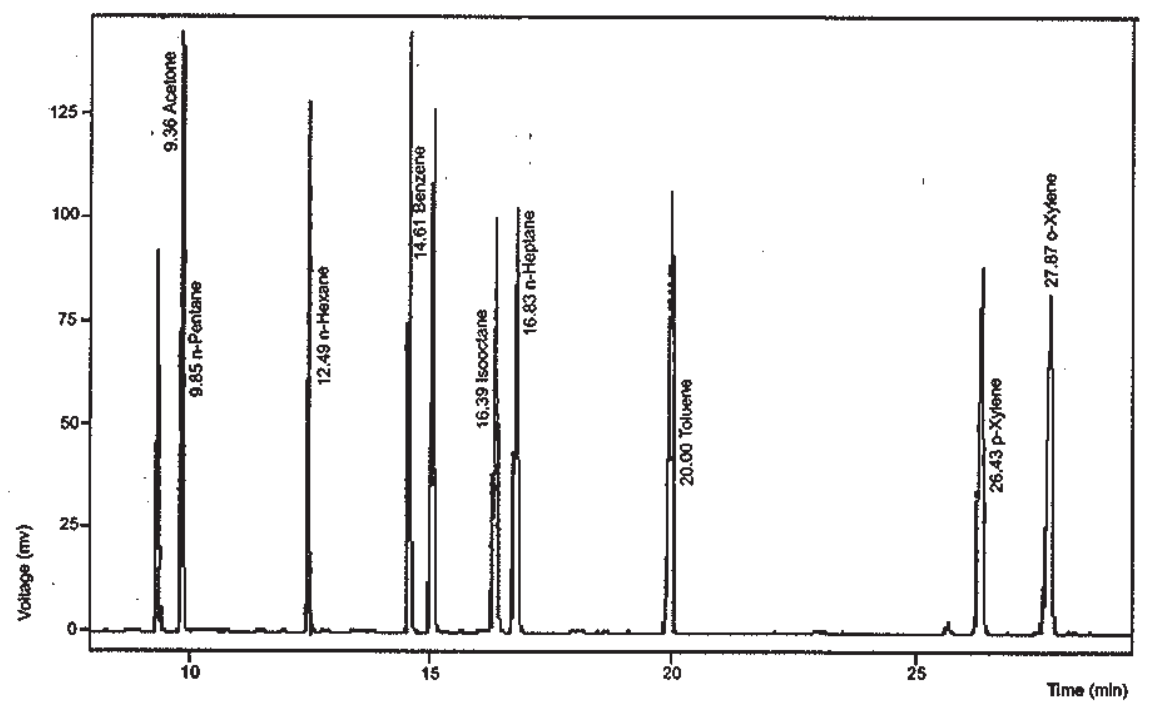


This is the result table for the Chromatogram 1.

\begin{tabular}{|l|r|r|r|r|l|l|}
\hline $\begin{array}{c}\text { Peak. } \\
\text { No }\end{array}$ & R.T & \multicolumn{1}{c|}{$\begin{array}{c}\text { Area } \\
\text { (mV.s) }\end{array}$} & \multicolumn{1}{c|}{$\begin{array}{c}\text { Amount } \\
\text { (ul) }\end{array}$} & \multicolumn{1}{c|}{$\begin{array}{c}\text { Amount } \\
\%\end{array}$} & Peak Type & Component \\
\hline 1 & 9.360 & 233.8034 & 62.6357 & 26.8694 & Ordnr & Acetone \\
\hline 2 & 9.847 & 343.1072 & 87.2323 & 37.4208 & Ordnr & n-Pentane \\
\hline 3 & 12.493 & 378.0441 & 14.8247 & 6.3595 & Ordnr & n-Hexane \\
\hline 4 & 14.607 & 544.4891 & 12.8811 & 5.5257 & Ordnr & Benzene \\
\hline 5 & 15.060 & 457.9062 & 11.5381 & 4.9496 & Ordnr & Cyclohexane \\
\hline 6 & 16.387 & 403.6193 & 10.3614 & 4.4448 & Ordnr & Isooctane \\
\hline 7 & 16.827 & 421.2618 & 10.6976 & 4.589 & Ordnr & n-Heptane \\
\hline 8 & 20.00 & 542.1897 & 7.8614 & 3.3724 & Ordnr & Toluene \\
\hline 9 & 26.427 & 554.621 & 7.0829 & 3.0384 & Ordnr & p-Xylene \\
\hline 10 & 27.873 & 511.2054 & 7.9964 & 3.4304 & Ordnr & o-Xylene \\
\hline- & Total & 4390.2473 & 233.1117 & 100 & & \\
\hline
\end{tabular}

It is used to find out the volume percent theoretically. For example the amount of volume injected in the mixture is $10 \%$, when calculate this using the theoretical calculation we get $9.96 \%$ as volume percentage, to avoid the disorder in the volume percentage we can use the auto sampler.

The second chromatogram shows the pure motor gasoline peaks and their retention Times, the result table given in annexure 1. This chromatogram represents all the components present in the motor gasoline.

The third one (chromatogram 3) shows extra peaks other than the normal motor gasoline. It represents a few specific peaks arise at some places/Rt, they clearly show that this petrol is an adulterated one.

Normally the GC software itself gives the area and area\%. Using the area and area \% we can find the adulterated solvents, but it is impossible to find all the solvents/adulterants. But we can find out the possible adulterants. 


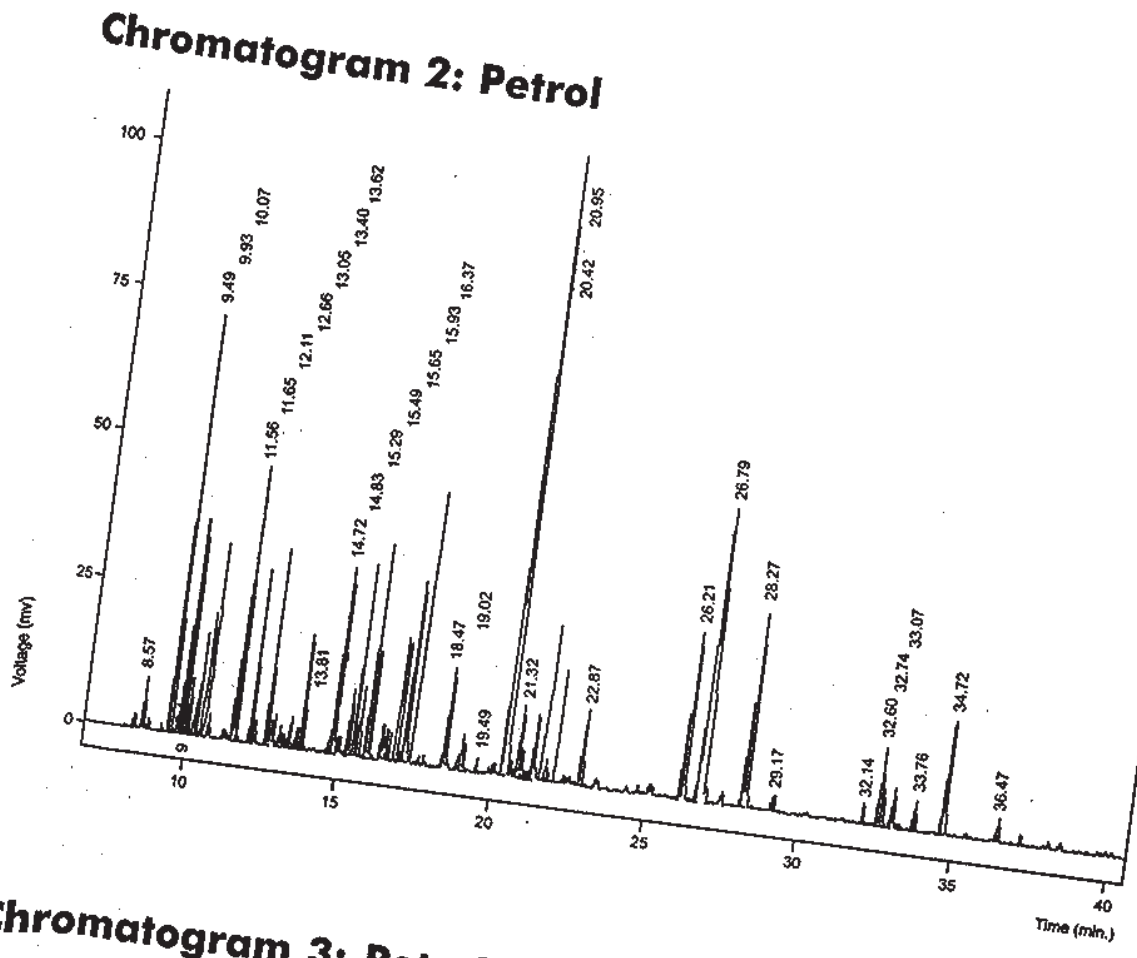

Chromatogram 3: Petrol (adulterated)

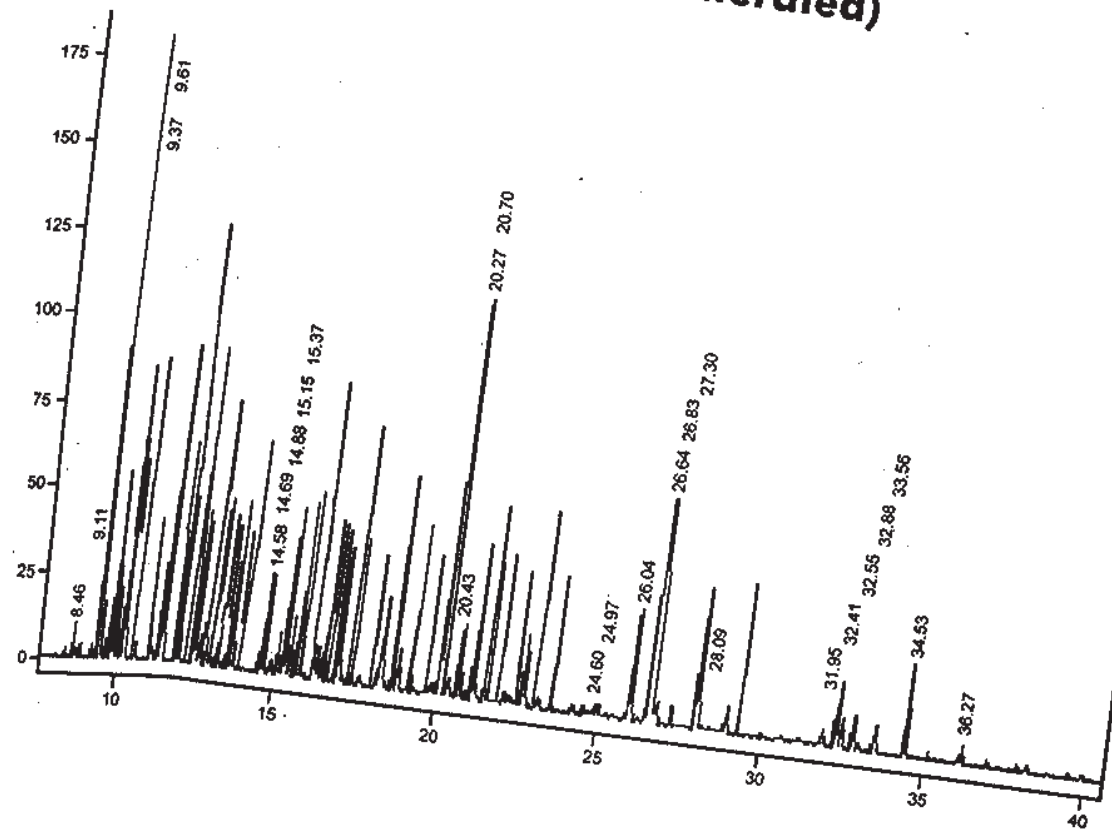




\section{Chromatogram 4}

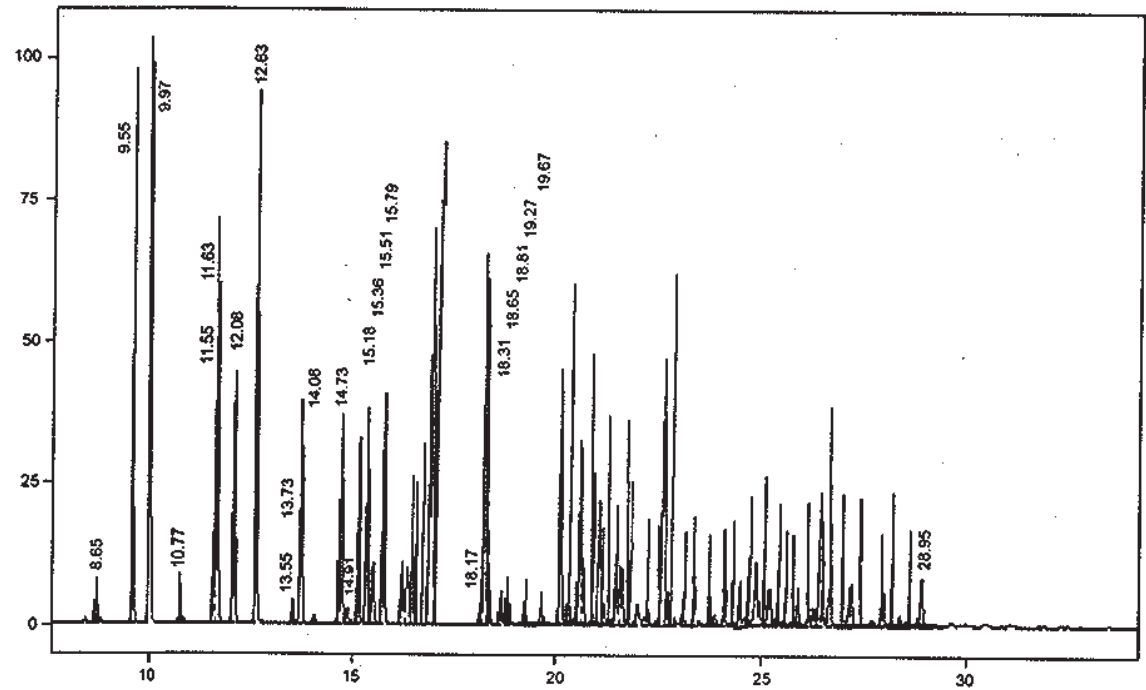

The above chromatogram shows peaks of the light aromatic naphtha that is available in the market, this shows the similar peaks like in the motor gasoline. The refineries use this for the blending purpose. The aromatic components are less in this sample and in area percentage.

\section{Chromatogram 5}

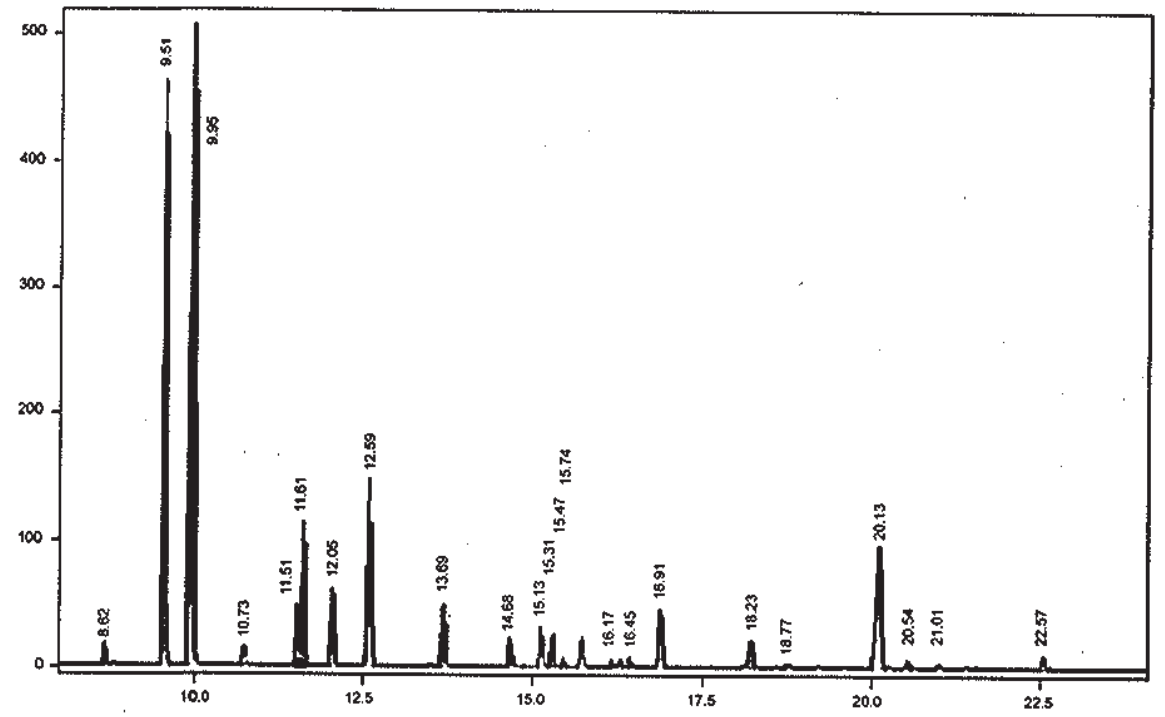


This chromatogram represents one of the SBP solvents, which shows that the lower saturated hydrocarbons predominantly present in this compound. This is the major adulterant available in the market. Normally motor gasoline has all the above components, but when the SBP solvent are added to the motor gasoline, the adulterated motor gasoline shows the higher percentage of these components. This clearly indicates that the particular motor gasoline is adulterated.

Let us compare the retention times of the SBP solvents. and light aromatic naphtha with the third chromatogram. SBP solvent present in the large amount shows that they are added as adulterant. The third chromatogram clearly shows that lower saturated hydrocarbons may be added as an adulterant. SBP solvents like n-butane, 1-butane, butene-2, n-pentane, 2-methylbutene-2, 2, 2-dimethyl butane, cyclopentane, 2, 3-dimethyl butane, 2-methyl pentane, 3-methyl pentane are present in higher amount in this sample. So adulteration may be possible using these solvents.

It is clear that the solvents are added as adulterants due to the cost factor, but they are not violating the specifications. This motor gasoline obeys all the specification given by the BIS. But the above chromatograms clearly show that the adulteration made using the solvents. Even though we find adulteration of few solvents it is impossible to find all the solvents, which are added in the least level. Without DHA we can find out a few possible solvents using the Gas Chromatography method.

\section{References}

1. American National Standard - (D 3606-99) page 1(3.1)

2. American National Standard - (D 5580-00) page 641(4.1)

3. American National Standard - page 1137 (3.1.10), (D 4815-99) \& Bureau of Indian Standard (IS 2796-2000) page 2(c-5.8)

4. Fuels and petroleum products - B.K. Sharma

5. Bureau of Indian Standards - IS 1448 (P: 18) pages 1-13; Table-1

6. Bureau of Indian Standards - IS-2796: 2000, page-2, table -1 (iv)

7. Benzene content - American National Standard - D3606 \& IS-2796: 2000, page-2, table-1 (xii)

8. Antiknocking Index - Bureau of Indian Standards - IS1 448 (P: 26) \& IS1448 (P: 27)

9. Flashpoint - Bureau of Indian Standards - IS 1448 (P: 20) pages 1-7

10. Pour point- Bureau of Indian Standards - IS 1448 (P: 10) pages $1-8$ 
11. Flashpoint - Bureau of Indian Standards - IS 1460: 2000, page-2, Table-1 (ix-b)

12. Kinematic viscosity- Bureau of Indian Standards - IS 1448 (P: 25) pages $1-8$

13. Split Ratio- American National Standard - (D 5580-00) page 64)(3.1.4)

14. Hrivnac. M, Frischknecht. W and Cechova. L, Anal.Chem 48(6), 937.

15. Blune. W, and Richter.W.J, J.Chromotogr. 132(2), 249 (1977)

16. Andreatch. A.J and Feinlared. R Anal.Chem, 32, 1021 (1960).

17. Giuffrida. L, In "Recent advances in Gas Chromatography" (1.J. Domsky and J.A. Perry. Eds.) Marcel Dekker, New York (1971) pp 125.135

18. Hill.H.H.Jr and Ave, W.A., J.Chromotogr.Sci 12(10), 541(1974).

19. Dupius. M.S. and Hill. H.H.Jr, J.Chromatogr. 195(2), 211 (1980).

20. Frohne. J.C, Erdoel Kohle, Erdgas, Petrochem 37(3), 123 (1964) (Ger)

21. Colson. E.R, Anol.Chem, 58 (2), 337 (1986).

22. Abdalla. S, F.Z. Anal.Chem. 328(3), 225 (1987).

23. Huang. Y, Ou.Q and Yu W, Anal. Chem 62(18), 2063 (1990)

24. Tsujino. $Y$ and Kuwata. K, J.Chromatogr. 642 (1-2), 383 (1993).

\section{Annexure 1}

The Result table for the Chromatogram 2.

\begin{tabular}{|c|c|c|c|c|c|}
\hline $\begin{array}{c}\text { Peak. } \\
\text { No }\end{array}$ & R.T & $\begin{array}{c}\text { Area } \\
\text { (mV.s) }\end{array}$ & $\begin{array}{c}\text { Height } \\
(\mathrm{mV})\end{array}$ & $\begin{array}{c}\text { WO5 } \\
(\mathrm{min} .)\end{array}$ & Area(\%) \\
\hline 1 & 8.573 & 17.9410 & 8.3529 & 0.0400 & 0.5603 \\
2 & 9.487 & 173.7524 & 71.5257 & 0.0467 & 5.4261 \\
3 & 9.840 & 20.5574 & 8.5690 & 0.0400 & 0.6420 \\
4 & 9.933 & 85.0234 & 36.4506 & 0.0400 & 2.6552 \\
5 & 10.067 & 23.2638 & 9.6657 & 0.0400 & 0.7265 \\
6 & 10.240 & 12.9611 & 5.2840 & 0.0467 & 0.4048 \\
7 & 10.340 & 42.8650 & 17.3778 & 0.0467 & 1.3386 \\
8 & 11.560 & 36.4280 & 13.6828 & 0.0467 & 1.1376 \\
9 & 11.647 & 121.2280 & 46.9691 & 0.0467 & 3.7858 \\
10 & 12.113 & 91.7811 & 29.4511 & 0.0467 & 2.8662 \\
11 & 12.660 & 124.9940 & 33.3380 & 0.0467 & 3.9034 \\
12 & 13.047 & 19.5279 & 3.3704 & 0.0600 & 0.6098 \\
\hline
\end{tabular}




\begin{tabular}{|c|c|c|c|c|c|}
\hline 13 & 13.400 & 14.6400 & 5.2844 & 0.0467 & 0.4572 \\
\hline 14 & 13.620 & 9.7864 & 3.3947 & 0.0467 & 0.3056 \\
\hline 15 & 13.807 & 75.3293 & 19.5611 & 0.0667 & 2.3525 \\
\hline 16 & 14.720 & 12.0049 & 3.6980 & 0.0533 & 0.3749 \\
\hline 17 & 14.833 & 107.4656 & 31.8003 & 0.0533 & 3.3561 \\
\hline .18 & 15.293 & 35.2237 & 11.3764 & 0.0533 & 1.1000 \\
\hline 19 & 15.493 & 104.7933 & 32.6870 & 0.0533 & 3.2726 \\
\hline 20 & 15.647 & 34.5168 & 11.7837 & 0.0467 & 1.0779 \\
\hline 21 & 15.933 & 118.5377 & 36.3680 & 0.0533 & 3.7018 \\
\hline 22 & 16.373 & 24.8666 & 5.6920 & 0.0533 & 0.7766 \\
\hline 23 & 16.513 & 17.4356 & 5.0549 & 0.0600 & 0.5445 \\
\hline 24 & 16.647 & 13.1224 & 4.5290 & 0.0533 & 0.4098 \\
\hline 25 & 17.120 & 118.9117 & 31.0840 & 0.0533 & 3.7135 \\
\hline 26 & 18.473 & 53.7591 & 16.4471 & 0.0600 & 1.6788 \\
\hline 27 & 19.020 & 22.4109 & 5.9170 & 0.0600 & 0.6999 \\
\hline 28 & 19.493 & 10.2429 & 2.4305 & 0.0667 & 0.3199 \\
\hline 29 & 20.427 & 563.0202 & 106.3854 & 0.0867 & 17.5826 \\
\hline 30 & 20.847 & 39.0147 & 12.1202 & 0.0600 & 1.2184 \\
\hline 31 & 20.953 & 19.4414 & 4.8687 & 0.0667 & 0.6071 \\
\hline 32 & 21.320 & 52.3014 & 11.1112 & 0.0600 & 1.6333 \\
\hline 33 & 21.727 & 16.5143 & 3.5372 & 0.0600 & 0.5157 \\
\hline 34 & 22.873 & 49.7522 & 12.8568 & 0.0600 & 1.5537 \\
\hline 35 & 26.213 & 117.9056 & 28.5483 & 0.0667 & 3.6821 \\
\hline 36 & 26.793 & 406.3812 & 50.3144 & 0.1400 & 12.6909 \\
\hline 37 & 28.267 & 146.8873 & 33.2787 & 0.0733 & 4.5872 \\
\hline 38 & 29.173 & 9.8805 & 2.6498 & 0.0600 & 0.3086 \\
\hline 39 & 32.140 & 13.3822 & 3.3861 & 0.0600 & 0.4179 \\
\hline 40 & 32.600 & 53.4595 & 13.5027 & 0.0667 & 1.6695 \\
\hline 41 & 32.740 & 23.4666 & 6.2005 & 0.0600 & 0.7328 \\
\hline 42 & 33.067 & 32.0973 & 6.7733 & 0.0667 & 1.0024 \\
\hline 43 & 33.760 & 20.5071 & 5.0044 & 0.0733 & 0.6404 \\
\hline 44 & 34.720 & 80.1263 & 19.0847 & 0.0733 & 2.5023 \\
\hline 45 & 36.467 & $14.6366^{\circ}$ & 3.7908 & 0.0667 & 0.4572 \\
\hline - & Total & 3202.1447 & 834.5585 & & \\
\hline
\end{tabular}

